\title{
MLL/MLLT11 Fusion Gene
}

National Cancer Institute

\section{Source}

National Cancer Institute. MLL/MLLT11 Fusion Gene. NCI Thesaurus. Code C105646.

A fusion gene that results from a chromosomal translocation $t(1 ; 11)(q 21 ; q 23)$ which fuses the first 6 exons of the MLL gene to the 5' untranslated region of the MLLT11 gene. This rearrangement is associated with acute myelomonocytic leukemia. 